\title{
PEMETAAN PEMAHAMAN AWAL PARA PELAKU USAHA FOOD TRUCK DI KAWASAN WISATA KOTA PADANG TENTANG HALAL TOURISM
}

\author{
Muhammad Ridwan, Muhammad Fadli , dan Larissa Navia Rani \\ Universitas Putra Indonesia YPTK Padang, Indonesia \\ fadli.caniago@gmail.com
}

\begin{abstract}
ABSTRAK
Penelitian ini bertujuan untuk memetakan pemahaman awal para pelaku usaha yang bergerak dalam food truck di kawasan wisata kota Padang mengenai konsep wisata halal (halal tourism). Penelitian ini mengunakan metodologi penelitian kuantatif dengan pendekatan survei. Metode sampling mengunakan stratifeid random sampling yaitu mengambil sampel secara acak porposional dari masing-masing jenis usaha food truck yaitu 30 orang pelaku food truck pada empat kawasan wisata di kota Padang. Indikator survei yang digunakan yaitu sebelas indikator sebagai alat ukur pemahaman mengenai halal tourism yaitu: (1) ramah keluarga, (2) keamanan, (3) jumlah kunjungan muslim, (4) jaminan kehalalan makanan dan minuman, (5) fasilitas sholat, (6) fasilitas bandara, (7) pilihan akomodasi, (8) kesadaran kebutuhan wisatawan muslim, (9) kemudahan komunikasi, (10) kemudahan visa, dan (11) dukungan pemerintah. Berdasarkan hasil penelitian diperoleh kesimpulan bahwa mayoritas responden dalam penelitian in telah memahami konsep wisata halal. Indikator yang paling dominan dipahami oleh responden adalah kesaradaran kebutuhan wisatawan muslim. Hal ini menunjukkan para pelaku usaha food truck di Kota Padang memiliki pemahaman awal yang baik mengenai konsep wisata halal.
\end{abstract}

Primary Key : Halal Tourism, Food Truck, Ekonomi Kreatif.

\section{Pendahuluan}

Indonesia merupakan salah satu destinasi wisata halal terbaik dari berbagai negara di dunia. Hal tersebut terlihat dari laporan Indikator Ekonomi Islam Global (GIEI) yang menempatkan Indonesia pada posisi ke empat dalam Indikaotr perjalanan halal. Kementerian Pariwisata pada trisemester awal tahuan 2017 merilis peningkatan kunjungan dari wisatawan mancangeara meningkat secara signifikan dari tahun 2017 yaitu 21,31\%. Dari capaian tersebut menunjukkan bahwa Indonesia memberikan kontribusi yang patut diperhitungkan dalam kegiatan wisata halal di benua Asia.

Kunjungan wisata ke Indonesia terus meningkat tidak saja terjadi pada tahun 2017. Jauh pada tahun sebelumnya Indonesia telah berkembang menjadi salah satu tujuan bisnis dan wisata, hal tersebut dirilis dalam Statistical Report on Visitor Arrivals to Indonesia tahun 2004-2006 yang menyebutkan kunjungan wisatawan mancanegara untuk pertemuan, insentif, konvensi dan pameran atau lebih dikenal dengan meeting, incentive, convention, exhibition (MICE) mencapai $41,23 \%$. Sementara untuk wisatawan yang datan dalam liburan 56,49\% dan lainnya 2,28\%.

Meningkatnya jumlah wisatawan yang berkunjung ke Indonesia tentu tidak terlepas dari peranan para pelaku usaha dalam memberikan produk jasa kepada para wisataawan. Disamping itu, berbagai jenis produk yang dipasarkan dalam mendukung kegiatan wisata juga memiliki pengaruh yang sanggat penting terhadap peningkatan kunjungan tersebut.

Sumatera Barat misalnya, merupakan salah satu provinsi di Indonesia yang telah menerapkan konsep wisata halal. Selanjutnya, Sumatera Barat merupakan salah satu prioritas dalam pengembagan wisata hahal. Hal tersebut dilihat dari upaya yang dilakukan oleh pemerintah provinsi dalam pelibatan masyarakan dari berbagai lapisan, dan lintas sektoral dalam mendukung terwujudnya wisata halal. Bergeraknya perekonomian masyarakat di daerah wisata merupakan 
tujuan utama pemerintah daerah dalam membangun sektor wisata, sehingga produk jasa yang ditawarkan dalam aktivitas wisata ini berkontribusi untuk kesejahteraan masyarakat.

Teriplihnya Indonesia sebagai destinasi perjalanan halal tersebut mengacu kepada sebelas indikator berikut ini: (1) ramah keluarga, (2) keamanan, (3) jumlah kunjungan muslim, (4) jaminan kehalalan makanan dan minuman, (5) fasilitas sholat, (6) fasilitas bandara, (7) pilihan akomodasi, (8) kesadaran kebutuhan wisatawan muslim, (9) kemudahan komunikasi, (10) kemudahan visa, dan (11) dukungan pemerintah. Perkembangan aktivitas wisata di Sumatera Barat telah mendorong berkembangnya industri pariwisata. Industri yang tumbuh untuk mendukung kegiatan pariwisata tersebut tentu tidak dapat terlepas dari akvitas wisata itu sendiri karena kegiatan wisata melibatkan searangkaian pengusaha penghasil baran dan jasa yang berbeda antara satu dengan yang lainnya.

Berbagai usaha ekonomi kreatif muncul pada daerah wisata, salah satunya adalah food truck yaitu berjualan makanan dengan menggunakan kendaraan seperti mobil yang menjajakan berbagai makanan kuliner. Food truck merupakan mobil yang dimodifikasi seunik mungkin hingga memiliki daya tarik tersendiri dalam memasarkan produk makanan. Kreatifitas pada pelaku usaha kuliner dengan mengunakan food truck ini memberikan sebuah nuansa untuk bersantap praktis, fleksibel dan terjangkau harga yang ditawarkannya. Berjualan dengan mengunakan mobil memang tidak hal yang asing lagi pada beberapa daerah wisata.

Pada kawasan wisata di Kota Padang terdapat beragam jenis makanan yang dijajakan oleh food truck seperti bakso, sate, nasi goreng, martabak, dan lain sebagainya. Terdapat perbedaan yang mendasar antara pedagang foodtruck dengan pedagang mobil lainnya (mobil berjualan sayur, dan sembako berkeliling) yaitu ada dapur untuk memproses makanan, dan cenderung terbapat pada menu tematis saja.

Wisata kuliner food truck belakangan ini telah berhasil mengeser kedudukan usaha jasa kuliner yang cenderung monoton, artinya konsepnya hanya itu-itu saja. Hal ini bukan berarti warung tenda atau lesehan akan gulung tikar karena kehadiran food truck ini. Bagi wisatawan tentu hal yang menarik dengan suasana duduk sambil mengerumuni mobil besar berisi berbagai jenis makanan segar olahan dapur berjalan dengan menu kreatif, praktis, dan tentunya berada di kawasan wisata.

Dengan menjamurnya berbagai food truck di kawasan wisata di Kota Padang sebagai Ibu Kota Provinsi Sumateara Barat yang memiliki visi wisata halal tourism. Perlu dilakukan sebuah pemetaan mengenai pemahaman awal pada pelaku usaha food truck mengenai konsep halal tourism. Berangkat dari fenomena tersebut peneliti melakukan kajian lebih lanjut mengenai penelitian ini.

\section{Kajian Literatur 2.1 Wisata Halal}

Pariwisata halal adalah konsep baru dalam indutri pariwisata. Wisata halal merupakan konsep yang diusung oleh masyarakat islam untuk memberikan kepastian dan kenyamanan dalam berwisata (Jaeni, 2017). Definisi wisata halal adalah kegiatan yang didukung oleh berbagai fasilitas serta layanan yang disediakan masyarakat, pengusaha, pemerintah, dan pemerintah daerah yang memenuhi ketentuan syariah menurut Kemenpar (Dini, 2015).

Wista halal memiliki perbedaan dengan wista konvensional, wisata religi, dan wisata syariah terdapat perbedaan yang mendasar antara wisata konvensional dengan wisata halal. Adapun tujuan dari wisata halal adalah meningkatkan kunjungan wisatawan dalam maupun luar negeri untuk mengunjungi berbegai destianasi maupun atraksi pariwisata yang memiliki nilai-nilai islami, yang tersebar di seluruh Indonesia. Tujuan lainnya adalah untuk mendorong tumbuh kembang bisnis syariah dalam industri pariwisata( $\underline{w w w . i n d o n e s i a t r a v e l})$. 
Tabel 1. Perbedaan wisata konvensional, wisata religi, dan wisata syariah

\begin{tabular}{|c|c|c|c|c|}
\hline No. & Aspek & $\begin{array}{c}\text { Wisata } \\
\text { Konvensional }\end{array}$ & Wisata Religi & Wisata Syari'ah/Halal \\
\hline 1 & Obyek & $\begin{array}{l}\text { Alam, budaya, } \\
\text { Heritage, Kuliner }\end{array}$ & $\begin{array}{l}\text { Tempat Ibadah, } \\
\text { Peninggalan } \\
\text { Sejarah }\end{array}$ & Semuanya \\
\hline 2 & Tujuan & Menghibur & \begin{tabular}{|l|} 
Meningkatkan \\
Spritualitas \\
\end{tabular} & $\begin{array}{l}\begin{array}{l}\text { Meningkatkan } \\
\text { dengan cara menghibur }\end{array} \\
\end{array}$ \\
\hline 3 & Target & $\begin{array}{l}\text { Menyentuh } \\
\text { kepuasan dan } \\
\text { kesenangan yang } \\
\text { berdimensi nafsu, } \\
\text { semata-mata hanya } \\
\text { untuk hiburan }\end{array}$ & $\begin{array}{l}\text { Aspek spiritual } \\
\text { yang bisa } \\
\text { menenangkan } \\
\text { jiwa. Guna mencari } \\
\text { ketenangan batin }\end{array}$ & $\begin{array}{lrr}\begin{array}{l}\text { Memenuhi } \\
\text { kesenangan }\end{array} & \text { keinginan } & \text { dan } \\
\text { menumbuhkan } & \text { serta } \\
\text { beragama } & & \end{array}$ \\
\hline 4 & Guide & $\begin{array}{l}\text { Memahami dan } \\
\text { Menguasai } \\
\text { informasi sehingga } \\
\text { bisa menarik } \\
\text { wisatawan terhadap } \\
\text { obyek wisata }\end{array}$ & $\begin{array}{l}\text { Menguasai sejarah } \\
\text { tokoh dan lokasi } \\
\text { yang menjadi obyek } \\
\text { wisata }\end{array}$ & 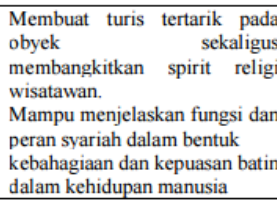 \\
\hline 5 & $\begin{array}{l}\text { Fasilitas } \\
\text { Ibadah }\end{array}$ & Sekedar pelengkap & Sekedar pelengkap & $\begin{array}{l}\text { Menjadi bagian yang menyatu } \\
\text { dengan obyek pariwisata, ritual } \\
\text { ibadah menjadi bagian paket } \\
\text { hiburan }\end{array}$ \\
\hline 6 & Kuliner & \begin{tabular}{|l|} 
Umum \\
\end{tabular} & \begin{tabular}{|l|} 
Umum \\
\end{tabular} & \begin{tabular}{|l} 
Spesifik yang halal \\
\end{tabular} \\
\hline 7 & $\begin{array}{l}\text { Relasi } \\
\text { Masyarakat } \\
\text { dan } \\
\text { Lingkungan } \\
\text { Obyek Wisata } \\
\end{array}$ & $\begin{array}{l}\text { Komplementar dan } \\
\text { hanya untuk } \\
\text { keuntungan materi }\end{array}$ & $\begin{array}{l}\text { Komplementar dan } \\
\text { hanya untuk } \\
\text { keuntungan materi }\end{array}$ & $\begin{array}{l}\text { Integrated, interaksi berdasar } \\
\text { pada prinsp syariah }\end{array}$ \\
\hline 8 & \begin{tabular}{|l|} 
Agenda \\
Perjalanan \\
\end{tabular} & Setiap waktu & $\begin{array}{l}\text { Waktu-waktu } \\
\text { tertentu }\end{array}$ & Memperhatikan waktu \\
\hline
\end{tabular}

\section{Karakteristik Wisata Halal}

Menurut Chukaew dalam Alim (2015), terdapat delapan faktor standar pengukuran pariwisata syariah dari segi administrasi dan pengelolaannya untuk semua wisatawan yang hal tersebut dapat menjadi suatu karakteristik tersendiri, yaitu : (a) Pelayanan kepada wisatawan harus cocok dengan prinsip muslim secara keseluruhan.(b) pemandu dan staf harus memiliki disiplin dan menghormati prinsip-prinsip Islam. (c) Mengatur semua kegiatan agar tidak bertentangan dengan prinsip Islam. (d) Bangunan harus sesuai dengan prinsip-prinsip Islam. (e) Restoran harus mengikuti standar internasional pelayanan halal. (f) Layanan transportasi harus memiliki keamanan sistem proteksi. (g) Ada tempat-tempat yang disediakan untuk semua wisatawan muslim melakukan kegiatan keagamaan (h) Bepergian ke tempat-tempat yang tidak bertentangan dengan prinsip Islam.

\subsection{Sejarah Food Truck}

Sistem operasional makanan yang berpindah-pindah dari satu tempat ke tempat lainnya atau yang lebih dikenal food truck. Pada dasarnya sudah mulai berkembang bersamaan dengan sejarah Amerika. Sistem ini sudah ada sejak tahun 1600 an, hal ini terbukti dengan adanya perdebatan antara "mobile food" dengan restoran tetap pada tahun 1961. Pada tahun 1980an pengusaha dari Texas yang bernama Charles Goodnight merupakan orang yang pertama kali mencetuskan ide pembuatan food 9 truck yang kemudian diberi nama "chuckwagon" Chuckwagon berbentuk seperti kereta dorong yang dilengkapi dengan berbagai macam peralatan seperti teko dan peralatan masak lainnya dengan sajian makanan rebusan, sapi panggang, bubur jagung, kentang dan pie buah. Chuckwagon mulai sering muncul di seluruh barat Amerika untuk memberi makan pengemudi ternak yang terus melintasi US.

Mulai semenjak itu perkembangan food truck semakin tahun semakin berkembang mulai dari bentuk gerobak dorong, gerobak yang ditarik oleh kuda sampai menggunakan mesin (Start Your Own Food Truck Business dalam Hawk, 2013). 


\section{Metodologi Penelitian}

Untuk mengungkapkan realitas di lapnagan mengenai pemahaman para pelaku usaha food truck mengenai konsep halal tourism penelitian ini menggunakan metode penelitian kuantitatif dengan pendekatan survey. Penelitian survey digunkan untuk mengadakan pemeriksaan dan pengukuranpengukuran terhadap gejala empris yang berlangsung di lapangan atau lokasi penelitian, umumnya dialkukan terhadap unit sample yang dihadapi sebagai responden dan bukan seluruh populasi sasaran (Fatoni, 2006).

Pengumpulan data penelitian diperlukan dari sumber yang mendukung perolehan kesimpulan dengan mengumpulkan data melalui wawancara, dan observasi langsung dilakangan, selanjutnya data sekunder diperoleh dari stui dokumentasi yang mengandung informasi yang berkaitan dengan penelitian ini. Sampel peneltian berjumlah 30 orang dengan memberikan kusioner yang berkaitan dengan indikator wisata halal. Selanjutnya, wawancara dilakukan dalam penelitian ini mengunakan teknik indepth interview dan semi terseturtur pada para pelaku usaha food truck yang ada di kota Padang.

Lokasi penelitian ini dilakukan pada kawasan wisata yang terdapat di Kota Padang. Hal tersebut dilatarbelakangi kota padang meurpakan pintu gerbang masuknya para wisatawan macanegara dan domestik masuk ke daerah Sumatera Barat, meskipun Bandara Internasional Minangkabau (BIM) berada di daerah Padang Pariaman, namun tujuan wisatawan pertama adalah ke Kota Padang.

\section{Hasil dan Pembahasan}

4.1 Jenis usaha food truck

Pada bagian ini, akan dideskripsikan hasil survei yang dilakukan di lapangan. Penelitian yang dilakukan dengan mengambil 30 sample penelitian terdiri dari berbagai jenis pelaku usaha, yaitu makanan, minuman, dan usaha lainnya yang bergerak dalam bidang makan dan minuman seperti (salad buah, juice). Berikut ini kategorisasi jenis pelaku usaha food truck berdasarkan jenis usaha yang dilakukan.

\section{SEKTOR USAHA PELAKU FOOD TRUCK DI KAWASAN WISATA DI KOTA PADANG}

\begin{tabular}{clcc}
\hline No & SEKTOR USAHA & JUMLAH & $\begin{array}{c}\text { PRESENTASE } \\
(\boldsymbol{\%})\end{array}$ \\
\hline 1 & Makanan & 8 & 27 \\
\hline 2 & Minuman & 11 & 36,5 \\
\hline 3 & Lainnya & 11 & 36,5 \\
\hline & Total & 30 & 100 \\
\hline
\end{tabular}

Sumber: Data Penelitian (2018)

Data tersebut menunjukkan $27 \%$ dari pelaku usaha food truck di Kota Padang dalam usaha makanan. Bentuk usaha tersebut berupa jajanan mulai dari tradisonal hinggal makanan western, seperti martabak, pizza, burger, hingga makanan lokal seperti sate dan lain berbagai jenis makanan lainnya. Selanjutnya $36.5 \%$ berupa usaha minuman, minuman tersebut dalam bentuk kopi, yogourt, air tebu, dan berbagai jenis minuman olahan lainnya. Sementara itu, $36.5 \%$ lainnya berupa jenis usaha food truck yang menjual mengkombinasikan antara makanan dan minuman, atau jenis usaha seperti salad buah. Peneliti mengkategorikan dalam bidang ini karena pelaku usaha melakukan usaha dalam dua kegiatan tersebut.

Berdasarkan data tersebut dapat disimpulkan, jenis usaha yang dilakukan para pelaku usaha food truck di Kota Padang pada lebih didominasi oleh usaha minuman, dan usaha kombinasi antara minuman dan makanan. 


\subsection{Pemetaan Pemahaman Pelaku Usaha Food Truck}

Penelitian ini merupakan penelitian tahap awal yang diarapkan dapat menjadikan gambaran mnegenai tingkat pemahaman para pelaku usaha food truck pada kawasan wisata di Kota Padang. Pemahaman awal merupakan sebuah cikal yang menentukan perilaku, maupun sikap seseorang terhadap sesuatu hal. Demikian juga halnya dengan pemahaman awal para pelaku usaha food truck, juga akan mempengaruhi tindaklanjut dari sikap dan perilaku baik kepada para pengguna jasa pariwisata, maunpun dukungan yang diberikan kepada pemerintah dalam menyukseskan program wisata halal yang dicanangkan pemerintah.

Dengan mengungkapkan realitas di lapangan mengenai pemahaman awal dari para pelaku usaha food truck, diperoleh data sebagai berikut ini.

\section{TABULASI DATA TINGKAT PEMAHAMAN PELAKU USAHA FOOD TRUCK TERHADAP HALAL TOURISM}

\begin{tabular}{|c|c|c|c|c|c|}
\hline \multirow{2}{*}{$\begin{array}{l}\mathbf{N} \\
\mathbf{O}\end{array}$} & \multirow[t]{2}{*}{ INDIKATOR WISATA HALAL } & \multicolumn{3}{|c|}{ TINGKAT PEMAHAMAN } & \multirow[b]{2}{*}{$\begin{array}{c}\text { TOTAL } \\
\%\end{array}$} \\
\hline & & $\begin{array}{c}\text { TIDAK } \\
\text { PAHAM } \\
(\%)\end{array}$ & $\begin{array}{c}\text { PAHA } \\
\text { M } \\
(\%)\end{array}$ & $\begin{array}{c}\text { SANGA } \\
\text { T } \\
\text { PAHAM } \\
(\%)\end{array}$ & \\
\hline 1 & Ramah Keluarga & 11 & 58 & 31 & 100 \\
\hline 2 & Keamanan & 8 & 58 & 33 & 100 \\
\hline 3 & Jumlah Kunjungan Muslim & 30 & 45 & 25 & 100 \\
\hline 4 & Jaminan Kehalalan Makanan dan Minuman & 16 & 62 & 22 & 100 \\
\hline 5 & Faslitas Sholat & 19 & 54 & 27 & 100 \\
\hline 6 & Fasilitas Bandara & 40 & 55 & 5 & 100 \\
\hline 7 & Pilihan Akomodasi & 25 & 71 & 5 & 100 \\
\hline 8 & Kesadaran Kebutuhan Wisatawan Muslim & 14 & 78 & 8 & 100 \\
\hline 9 & Kemudahan Komunikasi & 35 & 65 & 0 & 100 \\
\hline 10 & Kemudahan Visa & 92 & 8 & 0 & 100 \\
\hline 11 & Dukungan Pemerintah & 38 & 50 & 12 & 100 \\
\hline
\end{tabular}

Sumber: Hasil Penelitian (2018)

Indikator yang digunakan dalam penelitian ini terdapat sebelas indikator yang dirilis oleh Global Travel Index, yang terdiri dari sebelas indikator, diantaranya (1) ramah keluarga, (2) keamanan, (3) jumlah kunjungan musli, (4) jaminan kehalalan makanan dan minuman, (5) fasilitas sholat, (6) fasilitas bandara, (7) pilihan akomodasi, (8) kesadaran kebutuhan wisatawan muslim, (9) kemudahan komunikasi, (10) kemudahan visa, dan (11) dukungan pemerintah. Sebelas indikator ini merupakan parameter yang digunakan untuk menilai destinasi wisatawan muslim.

Berdasarkan data yang disajikan pada tabel tersebut terlihat yang paling dominan sangat dipahami oleh para pelaku usaha food truck adalah kesadaran kebuthan wisatawan muslim. Indikator nomor depalan ini terlihat data sebanyak $78 \%$ paham dan $8 \%$ sanggat paham, jika dikalkulasikan berarti $96 \%$ dari responden telah memahami bagaimana mengenai kebutuhan wisawan muslim. Hal ini berarti para pelaku usaha food truck sudah kebutuhan-kebutuhan para wisatawan sehingga mereka dapat menyediakan kebutuhan wisatawan muslim.

Membaca peluang pasar merupakan keunggulan yang dimiliki oleh para pelaku usaha food truck di Kota Padang. Hal tersebut berkorelasi dengan usaha yang dibuat. Misalnya di kawasan pantai, disediakan jenis minuman segar seperti es jeruk, aneka ragam bentuk jus dan segala jenis panganan halal lainnya. Disamping itu, mengenai penyediaan fasilitas seperti tempat duduk bagi 
para pengunjung yang membeli makanan dan minuman. Hal tersebut sesuai dengan ajaran Agam Islam.

Dari Anas bin Malik radhiyallahu 'anhu, ia berkata,

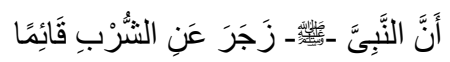

"Nabi shallallahu 'alaihi wa sallam sungguh melarang dari minum sambil berdiri."

(HR. Muslim no. 2024).

Bila dilihat lebih lanjut, jika pemahaman mengenai kehutuhan muslim sudah dipenuhi oleh para pelaku usaha, maka diyakini seluruh kebutuhan muslim dalam berwisata tentu akan terpenuhi.

Selanjutnya data hasil pemetaan di lapangan, terlihat yang tidak dipahami oleh pelaku usaha food truck adalah mengenai pengurusan visa wisatawan, dan dukungan pemerintah. Mengenai pengurusan visa hal ini memang tidak bersentuhan langsung dengan kegiatan food truck karena mengenai perizinan untuk tinggal lebih cenderung dilakukan oleh pihak keimigrasian dan pemerintah.

Satu hal yang menarik perhatian yaitu para pelaku usaha food truck belum memahami bagaimana bentuk dukungan yang diberikan oleh pemerintah dalam mendukung wisata halal. Berdasarkan temuan di lapangan, para pelaku usaha mengeluhkan minimnya sosialisasi dari pemerintah khususnya bidang yang terkait mengurusi masalah pariwisata dan ekonomi kreatif. Kegiatan diseminasi mengenai program wisata halal tersebut dapat dilakukan dalam bentuk pelatihan/workshop atau dalam bentuk seminar. Selanjutnya pemerintah juga dapat mengandeng pihak perguruan tinggi, dan praktisi ekonomi kreatif lainnya untuk membuat sebuah panduan (guidline) yang dapat memudahkan para pelaku usaha food truck dalam memahami kegiatan wisata halal.

\section{Kesimpulan}

Berdasarkan hasil penelitian dapat disimpulkan beberapa hal berikut ini.

1. Para pelaku usaha food truck di Kota Padang telah memahami mengenai indikator wisata halal khususnya mengenai kebutuhan wisatawan muslim.

2. Para pelaku usaha food truck di Kota Padang belum memahami bagiamana proses pengurusan perizinan visa, bagi wisatawan dan dukungan pemerintah dalam wisata hahal. Sehingga perlu pemerintah melakukan sosialisasi lebih lanjut dalam bentuk pelatihan, sosialisasi dan lain sebagainya dengan mengandeng berbagai pihak yang terkait. 


\section{DAFTAR PUSTAKA}

Kementerian Pariwisata. 2015. “Laporan Akhir Kajian Pengembangan Wisata Syariah”. Deputi Bidang Pengembangan Kebijakan Kepariwisataan.

Hadiwijoyo, Suryo Sakti. 2012. Perencanaan Pariwisata Berbasis Masyarakat (Sebuah Pendekatan Konsep). Yogyakarta: Graha Ilmu

Jaelani, Aan. 2017. Halal Tourism Industri in Indonesia: Potential and Prospects. Faculty of Shari'ah and Islamic Economic, IAIN Syekh Nurjati Cirebon. Online at https://mpra.ub.uni-muenchen.de/76237/

Suharko, dkk. 2016. Presentasi Research Days tanggal 22 November 2016 yang berjudul "Strategi Pengembangan Kelembagaan Kepariwisataan Berorientasi pada Halal Tourism: Studi di Destinasi Pariwisata Nasional Lombok-Gili Tramena".

Sunaryo, Bambang. 2013. Kebijakan pembangunan destinasi pariwisata. Yogyakarta: Gava Media

Sureerat Chookaew et al. 2015..Increasing Halal Tourism Potential atAndaman Gulf in Thailand for Muslim Country, Vol 3, no 7,

Theodorus B. Hanandoko, Jonantan Umum Naramburu Kapita. 2016. Riset Pasar Food Truck Ayam Bakar. Seminar Nasional IENACO-2016. ISSN: 2337-4349.

Undang-Undang Nomor 10 Tahun 2009 tentang Pariwisata 